\title{
PUBLIC POLICY AND RELIGIOUS CONFLICT IN INDONESIA: THE CASE OF AHMADIYAH
}

\author{
Ari Ganjar Herdiansah
}

Department of Political Science, Faculty of Political Sciences, Padjadjaran University

E-mail: ari.ganjar@unpad.ac.id

\begin{abstract}
Religious conflicts have become raised significantly after political reform in Indonesia. One of among conflict cases is Ahmadiyah sect as struggling minorities who spreading their influence in the middle of Sunni Islam majority. The conflict escalated and manifest in violence during the 2000s. The government eventually enacted Joint Ministerial Decree (SKB 3 Menteri) in 2008, which constrained preaching activities of Ahmadiyah who being accused of heresy. However, the decree did not stop the violence against Ahmadiyah. The conflict of Ahmadiyah was not solely about the heresy that charged on the Ahmadis, but also involving the contest of values, ideas, and authority between the liberal and pluralist Muslim groups versus the conservative Muslim groups. While the policy embodies controversial state as it perpetuates majority domination as well as close opportunities for constructive dialogues between the conflicting parties, this article views it as a resolution to anticipate the worst scenario. Therefore, the state's role as a policy maker is still needed to actualize social order, national stability and keep the democratic life under control.
\end{abstract}

Key words: religious conflict, public policy, democracy, social order.

\section{INTRODUCTION}

Ahmadiyah is a minority sect who has an intersection with Islam. However, their teaching is contradicted extremely with the central belief of Sunni Islam. For example, they are admitting the founder, Mirza Ghulam Ahmad, as a prophet after Prophet Muhammad. Certainly almost Muslim groups in Indonesia reject their missionary effort. Therefore, Ahmadiyah followers have been under pressure since its emergence in the country about 90 years ago. Nevertheless, after the political reform of 1998, the pressure on them was shifting into violence: the mob dissolute their rituals, destruct the mosques and persecute their members. Ahmadiyah is dealing with conservative Islamic groups that represent the majority Muslim in Indonesia. Among others are FPI (Islamic Defender Front), FUI (Islam Ummah Forum), GARIS (Islamic Reform Movement), LPPI (Institute for Research and Islamic Studies), and FUUI (Indonesian Ulama Ummah Forum) who supported by a semistate religious organization, MUI (Indonesian Council of Ulama).

In 2008, the government issued a Joint Ministerial Decree prohibiting Ahmadiyah missionary activities and rituals openly. The policy is considered to be contrary to the democracy and human rights principle that guarantees freedom of individuals or groups in performing their religious rituals (As'ad, 2009: 400). Interestingly, Fuller (2011: 3) shows that Ahmadiyah decree ironically triggers more severe marginalization and violence against the Ahmadis. Therefore, the decree was seen as the state's position in favor of the majority power and failed to protect the minority group interest (Crouch, 2009: 3).

Various studies have concluded that the imposition of Ahmadiyah decree was a setback for Indonesia democracy. The International Crisis Group report entitled Indonesia: Implications of the Ahmadiyah Decree (2008) states that the enactment of the Ahmadiyah decree was the point of a movement toward a model of Saudi Arabia that would banish religious freedom in Indonesia. Other studies express the causes of Ahmadiyah conflict. Burhani (2014: 1) reveals that the violence against Ahmadiyah is due to their vague position between the Islamic and non-Islamic. Non-Muslim or infidel groups are relatively safer from the majority oppression because Islam has the arrangement to set up social relations with them while there is no place for the heresy. Moreover, the violence against Ahmadiyah was also affected by the 
strengthening of intolerance since the fall of the authoritarian regime in 1998. Hicks (2013: 15) shows that the Ahmadiyah conflict was also caused by the political and authorities competition dimension among religious leaders. Fanani (2011: 27) utters that the violence on Ahmadiyah was a result of the strengthening of local political leaders who gain political benefit by displaying the traditional interpretation of the Sharia. Nevertheless, a little of those studies highlight the decree as a policy that managed to counterweight social order after the conflict got escalated and widen among liberalist and pluralist groups versus conservative Muslim groups.

This article focuses on the conflict escalation around Ahmadiyah decree enactment that involving two contentious Islamic groups, liberalist and pluralist groups versus conservative groups. The central argument of this paper is that instead intended as a resolution for Ahmadiyah, the decree had curbed the worst scenario of those groups that have access to mobilize a large amount of masses. This article probe on how the decree enactment, although considered has injured human rights, should be seen as a public policy that seeks to bring back social order in the midst of the national chaos threat. The preservation of social order becomes the priority on public policy process when the government distracted between the opposing interest groups.

\section{Public Policy On Religious Affair}

The Ahmadiyah decree is a public policy product. We shall understand the process and characteristic of it as part of the democratic system that involves civil society's role. The involvement of civil society in public policymaking process is a prerequisite of a democratic system (Sewell, 2005: 95). This is to ensure the civil society, groups participation and reducing the state dominance in public policy making (Ingram \& Smith, 2011: 4). However, citizen participation does not necessarily produce a democratic public policy. Luton (1996: 194) reveals there are less desired impacts from the overwhelming of citizens participation in public policymaking: (1) when the citizen's participation is too high, the implementation of public policies will be constrained due to the strain of groups intervention, (2) participation of citizens too sporadic and fragmented so the public policies generated are less effective in addressing social problems, (3) the overwhelming participation can drive public policy in the hands of the wrong people and bring the wrong policy.

The policy itself is inseparable from various and contested orientations or interest among civil society groups. Even in the most democratic country, there are still plenty of civil society groups who struggle for their religious belief. Therefore, the government produces policies that rule religious affair, such as marriage, funeral, and divorce. However, for some people, the state involvement in religious affair is considered as insufficient. They are demanding the state to enact more religious public policies. But for some people, the policies are excessive and call the government to handle it down (Sharkansky, 1996: 2). This is relevant to the distinction view between libertarians and conservative about how the government should intervene through public policy. Libertarians invoke the state to minimize interference in economic and social policy and believe that private bore better results than government intervention. On the other hand, conservatives' view that individual freedom should be limited to preserve social order and fulfill the rights of communities (Carrow, 1998: 6). However, regardless of the debate, the government has the authority and legitimacy to impose policies in urgent circumstances, to resolve the social conflict for example (Dukes, 1996: 15).

The process of public policy cannot be separated from political influence as political parties and civil societies continue to struggle their interests. There are several theories explaining how the political forces influencing the public policy making. State-centered theory sees the state as an autonomous actor who generally unresponsive to outside influences. Pluralist theory considers the parties outside the government influence the policy. Proponents of this theory lately focused on the role of public opinion and influence policy making (Peoples \& Gortari, 2008: 44). This study looks the public policy process in the dynamic movement between the state that prioritizes national stability (state-centered) amid the demands of various civil societies (pluralist). 


\section{The Nature Of Religious Conflict}

Whenreligious groupshavediscordinterest and tarnishing each other in an object, there would be a tense conflict. Although each religion called peace, but the claims of divinity remain a subject to ignite conflict (Gort\& Vroom, 2002: 4). The contentious groups would also interfere the government through a policy that could comply with their interests. Sociologically, one form of social conflict resolution in case majority against a minority is done through coercive regulation, in which minority groups are required to comply (Kriesberg, 1973: 108). However, the increasing openness of claims of ethnic, religious, and racial in modern society urged the government to issue an affirmative policy towards minority groups (Wilensky, 2002: 4). They who are affected by a government's policy should also be provided the opportunity for struggling their demands (Woll, 1981: 14). In this situation, the government holds an awry position. They are accused as undertake discrimination to the minority, supporting the majority, or violating the fairness.

Despite government intervention, religious conflicts are often difficult to overcome for several reasons. First, there are cultural differences that could lead to conflict. Second, it is ascriptive which means the intergroup membership shift is almost impossible. Thirdly, they tend to fight for unity and achieve territorial sovereignty (Schlee, 2010: 4). The difficulty of handling religious conflict is also caused by the nonrealistic conflict characteristics where there is no practical motive in it but the conflict itself. According to Coser (Rodgers, 2003: 95), nonrealistic conflict is often used as a way to release tension, frustration, and strengthens the identity of a person or group. Non-realistic conflict is harder to relieved due to unclear objectives of both parties.

Basically, it is hard to see that there is really religious matter within the intergroup religious conflict. Religious conflicts are socially constructed, where the process is mostly driven by the problems at the elite level (Svensson, 2013: 7). In Indonesia, social conflicts that contain religious dimension are influenced by social, economic and political factors. Such as the conflict of Nahdlatul Watan, Lombok, occurred between two descendants of a charismatic scholar who found the largest Islamic organization in the island. Raehan and Raehanun supporters are fighting over leadership succession (Hamidi \& Smith, 2012).

The bloody conflict that occurred in 1999-2002 in the Moluccas between the two major camps, Christian and Muslim, have caused tens of thousands of casualties on both sides. Although the polarization of the conflict based on religious identities, but the perception that the conflict is due to the religious factor is very weak and is only supported by radical groups. The moderate Muslim groups do not see the conflict as a religious matter. They believe the conflict caused by the interests of the political elite and the tendency of groups to act violently (Ali, 2007). Wilson (2008: 8) who conducts studies ethnoreligious conflict in North Moluccas in 1999-2000 revealed that the conflict merely motivated by economic competition and political power among ethnic groups that has been fragmented since the days of colonialism and maintained in the era of authoritarian regimes. Those characteristic features of religious conflicts in Indonesia directing this study to browse the social factors around Ahmadiyah conflict.

\section{Ahmadiyah: The Escalating Conflict}

Ahmadiyah sect was born in Punjab, India in 1890s. Mirza Ghulam Ahmad, who declared himself as the messiah, founded the sect. Ahmadiyah opposed by many Muslims, especially Sunnis because his teachings are considered contrary to Islamic teachings, such as claim that Mirza can speak to God and he is a prophet. In 1974, the Muslim World League issued a fatwa declaring Ahmadis as outlawed group and should be placed as non-Islam (As'ad, 2009: 394-395).

Ahmadiyah then split into two parties after Mirza died in 1914. The first party called themselves Ahmadiyah Qadiyani led by Mirza's son, Mahmud Ahmad. The second is Ahmadiyah Lahore led by Muhammad Ali and Kwaja Kamal Al-Din. The parting of Ahmadiyah was not just a matter of succession, butalso contrast differences in doctrine. Qadiyani considers Mirza Ghulam Ahmad as a prophet and treat an outsider as the infidel. On the contrary, the Lahore teaching was friendlier towards Muslims. They do not consider Mirza Ghulam Ahmad as a prophet and did not consider an outsider as the infidel (As'ad, 2009: 395). However, most Muslims do 
not recognize the distinction between Qadiyani and Lahore and treat them all as Ahmadiyah.

Ahmadiyah Lahore came to Indonesia in 1924 to conduct missionary activities in Yogyakarta by Mirza Ahmad Wali and Maulana Ahmad Baig as preachers. While Ahmadiyah Qadiyani arrived in 1925, when students from Indonesia studying in Qadiyan, Rahmat Ali, went home and began to spread the teachings of Ahmadiyahin Sumatra. The ulamainSumatra, then balked Ahmadiyah because their teaching was considered heretical and the followers charged as an apostate. However, the Ahmadiyah could survive the onslaught of rejection. On December 16,1935 , Qadiyani group set up headquarters in Jakarta under the name Qadiyan Department Ahmadiyah Indonesia. In 1949, they changed the name of the organization into Jemaah Ahmadiyah Indonesia (JAI). The organization is a branch of the Ahmadiyah caliphate centered in Qadiyan, India. The Ahmadiyah Lahore chose not to set up an organization and did not recognize the Qadiyan Caliphate (As'ad, 2009: 397).

JAI was trying to obtain a legal acknowledgment from the Indonesian government. His efforts were successful on March 13, 1953, after the Ministry of Law issued a ministerial decree No. JA.5 / 23/13. In 2003, the existence of JAI legalized as Community Organization by the Directorate for Relations with Political Institutions of the Ministry Home Affairs through decree No. 75 / DI / VI / 2003 (As'ad, 2009: 398).

The first refusal of the Ahmadiyah done by Nahdlatul Ulama (NU), the largest Islamic organization in Indonesia. In 1935, NU issued a fatwa declaring Ahmadiyah heretical teachings and stated that the followers belong to infidels and apostates. In 1980, after performing an exploration on 9 books of Ahmadiyah teachings, the MUI declared Ahmadiyah as a deviant, perverted, and non-Islamists sect. In 1984, MUI issued another fatwa to clarify the previous fatwa that strays Ahmadiyah (As'ad, 2009: 400). Currently, the number of followers of Ahmadiyah estimated as many as 400,000 people. A number of very minor compared to the 250 million people in Indonesia, which almost 90 percent are Muslim (Hicks, 2013: $3)$. Interestingly, there is a similarity between Ahmadiyah and conservative Islamic groups, both of them are militants who fight to repel Christian missionaries (Ropi, 2010: 295). However, that semblance cannot unite them as each side is mutually tarnished.

In the post-reformation period, the movement to challenge Ahmadiyah was rebound. In January 2005, a unit of the attorney who in charge to monitor religious sect held a meeting to discuss religious issues, such as Falun Gong and the Ahmadiyah sect issue. The meeting was attended by representatives of the police, military, Indonesian Intelligence Bureau (BIN), MUI, and several ministries. At the meeting, representatives of MUI recommended the government banning Ahmadiyah activities because of heresy and blemishing Islam (International Crisis Group, 2008: 2). The development of Ahmadiyah in the post-reform era was also got surveillance and oppression from hardline Islamic conservative groups like the FPI and GARIS, which stretch their muscles since the fall of the authoritarian regime (Hicks, 2013: 7).

On 9 July 2005, a number of conservative Islamic groups, among others FUUI, FPI, and LPPI led an attack on Ahmadiyah in Parung Bogor that wounded eight people. Responding to the solicitudes, the government re-activated an institution that in charge to conduct surveillance to the defiant sect that could disturb public order, namely Coordination Agency Monitoring Mystical Beliefs in Society (Bakorpakem) (International Crisis Group, 2008: 3). One of their tasks at that time was kept watching on Ahmadiyah activities. At the 7th congress in the same month, the MUI issued a fatwa declaring Ahmadiyah heretical from Islam. Those who follow the Ahmadis declared as an apostate. MUI invited the congregation Ahmadiyah back on the straight doctrine (Islam) if they still claim to be Muslims and called the government to stop the Ahmadiyah missionary activity (Fuller, 2011:9).

The conflict dimension was broadened when Ahmadiyah sect supported by liberalist Islamic groups and pluralist civil societies. Lutfi Assyaukanie, the leader of JIL (Liberal Islam Network), was very intense in opposing MUI and Islamic conservative groups regarding Ahmadiyah fatwa. On the pluralist side, a humanitarian civil society named The Wahid Institute, which founded by Abdurrachman Wahid, persistently countering Ahmadiyah 
discrimination. Oddly, Wahid was the most prominent figure of $\mathrm{NU}$, which at the grass root level of the organization there was a strong rejection against Ahmadiyah. NU scholars had been struggling to dissolve the influence of Ahmadiyah in East Java since the 1920s. But today, Wahid and his colleagues have an agenda in promoting pluralism in socialreligious life including standing on Ahmadiyah. This condition has made the difficult position between several NU elites and its grass root regarding Ahmadiyah even though it never caused a conflict within their organization. Instead, the quarrel got heated up between Wahid followers against Islamic conservatives, especially FPI which backed by thousand partisans. On the other side, the Wahid, who was a descendant of NU founder, also have a vigorous access to several militant Islamic mass organizations such as Garda Bangsa, GP Ansor, and Banser NU. The circumstance was going wild and certainly placed the two masses in binary position that could lead to a severe social conflict anytime.

The conflict between the Wahid and FPI got escalated when Abdurrachman Wahid defends the existence of Ahmadiyah in front of FPI mass at a meeting in Purwakarta in May 2006. Wahid then accused the leaders of the group who attacked Ahmadiyah are the ones who paid by unnamed General. Those statements made FPI leaders angered and then expelled Wahid from the city. The aftermath of the events in Purwakarta has fueled tensions between FPI and Garda Bangsa. In the next event in Demak, Central Java, a mass of Garda Bangsa blocked the arrival of Habib Riziek, the FPI leader, who would give a speech at an Islamic boarding school. Garda Bangsa even intended to march to Jakarta to crush the FPI headquarters. Luckily the police had managed to prevent Garda Bangsa mass convoy so that the bloody conflict could be avoided (International Crisis Group, 2008: 4).

The conservative then gave more pressure to the government to dissolve Ahmadiyah. They thought the escalating and widening conflict would never meet a solution as long as the Ahmadiyah still conduct their activities. However, Abdurrahman Saleh, the Attorney General, had asked JAI leaders to set a dialogue with the Ministry of Religion official before the attorney submit recommendations to the president about Ahmadiyah dissolution. The results of September 2007 meeting brought out twelve points of the JAI statement to the ministerial team, among others, "(1) we Recite the declaration of faith that there is no God but Allah, and Mohammed is his Prophet; (2) we believe that Mohammed was the final prophet; (3) we believe Mirza Ghulam Ahmad to be a teacher and mentor, who inspired his followers to Strengthen the teachings of Islam as brought by the Prophet Mohammed; (4) in the induction Oath of Ahmadiyah we use the word "Mohammed" before "Prophet of God"; (5) we donot believethat divinerevelationofIslamiclaw took place after the Holy Koran was revealed to Mohammed; and we follow the teachings of the Koran and the Prophet Mohammed; and (6) the Tadzkirah is not the holy book of the Ahmadiyah but a series of notes on the spiritual experience of Mirza Ghulam Ahmad that were compiled in 1935, 27 years after his death" (International Crisis Group, 2008: 5).

However, the twelve points of Ahmadiyah statement did not please MUI and the conservative groups anyway. They assumed the statements were multiple interpretations. The FPI and FUUI then continued to demand the Ministry of Religion to ban Ahmadiyah totally. On July 2007, Bakorpakem revealed the observations result on how the JAI really committed to the twelve statements on their practical realm. Based on their investigation, the JAI was assessed as inconsistent running their statement points and continue to implement the teachings that deviate from Islam that practiced in Indonesia, so JAI actions are deemed could threaten public order. Therefore, Bakorpakem reminded JAI to stop missionary activity or being dissolved. At the same time, Bakorpakem still recommended the government to issued a decree that could stop the activities of the Ahmadiyah sect (International Crisis Group, 2008: 6).

The president did not respond the recommendation ofAhmadiyahdissolutionimmediately. The members of President Advisory Council were split in addressing Ahmadiyah dissolution option. The council member who also represents MUI, Ma'ruf Amin, supports the disbanding Ahmadiyah option. While Adnan Buyung Nasution, a council member who 
also a national human rights lawyer, saw the dissolution option would violate the constitution that guarantees the religious freedom. Other council members were also disturbed by Ahmadiyah, but prefer persuasive measures so the Ahmadiyah followers could follow back the teachings of Islam. The diverse point of view in the council has made the government decision on Ahmadiyah prolonged (International Crisis Group, 2008: 6).

Meanwhile, the liberalist and pluralist groups were kept on expressing their support to Ahmadiyah through street demonstrations, which ignited open conflict with their opponent. On June 8, 2008, masses of FPI and Hizbuth Tahrir Indonesia (HTI) overwhelmed Monas Jakarta protesting the fuel price rising policy. At the same time, AKKBB (National Alliance for Freedom of Religion and Belief) mass and human rights activists conducted mass rally demanding pluralist tolerance and fighting radicalism. Although the police sought to dispel the mass from AKKBB to stay away from FPI and HTI, but the clash was unavoidable. Some activists of The Wahid Institute that joined in AKKBB were wounded. NU militia groups, then took revenge actions. In Cirebon, a mass from NU destroyed FPI signpost because their leader, Maman Immanulhaq Faqieh was one of the victims in Monas incident (Antaranews. com, 2008). In Jakarta, GP Ansor, a youth organization under NU, demanded the government to dissolve FPI otherwise they would disband FPI with their own force (NU. or.id, 2008). The Incident became a national issue and the president stated that the violence would never be accepted.

Realized the Ahmadiyah issue was the trophy of discord, on June 9, thousands of people from the conservative groups held a demonstration in front of the presidential palace demanding the dissolution of Ahmadiyah. Considering the critical condition, three ministries then imposed a decree ordering Ahmadis to not perform their religious activities in public places. The policy actually did not match the desires of conservative groups who persist dissolution option because the decree still allowed Ahmadiyah religious activity. It strengthens a supposition that the Ahmadiyah decree was more intended to prevent larger conflicts, especially between Wahid supporters with FPI and other conservative groups (International Crisis Group, 2008: 7).

The enactment of Ahmadiyah decree was quite effective to anticipate the bloody conflict between two great masses that were not hesitating to use violent means. However, the policy does not immediately stop the mass repressive actions against Ahmadiyah in many regions. On June 11, 2008, a mob attacked an Ahmadiyah mosque in Palembang but was foiled by the police. On June 18, six Ahmadiyah mosques in Cianjur sealed by about 100 people who call themselves followers of Ahlussunah Waljamaah. On June 20, FPI sealed an Ahmadiyah mosque in Makassar, South Sulawesi, a mob sealed two Ahmadiyah mosques in Cianjur and dozens of people blocked an Ahmadiyah mosque in Tangerang. On June 26, a mob sealed Ahmadiyah mosques in Cianjur and clashed with the police (International Crisis Group, 2008: 8).

The violence against Ahmadis still continued. In February 2011, the attack on Ahmadiyah in Cikeusik, Banten, has killed three Ahmadis. The incident depicts the religious intolerance in Indonesia was getting worse (Fuller, 2011: 5). The state was unable to protect its citizens from the issue of religious diversity. On the other side, the position of Ahmadiyah is also difficult because they are always being perceived attacking the central teachings of Islam, such as acknowledging Mirza as a prophet after Muhammad and have a holy book other than the Koran. Such teachings are not only annoying but also hurt almost all Muslims in Indonesia. A growing perception was put Ahmadiyah as a sturdy heretic who struggle to bend Islam. As a result, the discourse of violence against the Ahmadis less attracted the public sympathy.

International Crisis Group (2008: 16) reports that the enactment of Ahmadiyah decree was also influenced by the political interests, especially regarding the presidential election in 2009. President of Indonesia at the time, Susilo Bambang Yudhoyono, was eager to accommodate the government coalition parties who have helped deliver him as president in 2004 to regain support in 2009 election. Among the coalition parties are Islamic ones, such as PKS, PPP, and PBB who tend to represent conservative values and also gave concern on Ahmadiyah issue. However, this allegation is 
too far because the decree actually did not ban Ahmadiyah and the conservative groups yet unsatisfied with the policy. Thus, the practical political impetus behind the decree has no strong correlation.

\section{Public Policy And Social Order}

The violence committed by conservative groups against Ahmadiyah is inseparable from the dialogue deadlock. Since the bloody tragedy in Cikeusik, some religious leaders urged the government to facilitate dialogue between religious groups addressing the issue of Ahmadiyah. The issues grown in society were misinterpreted and encouraged the intensity of violence against the Ahmadis. Dialogues among conflicting parties have never reached the meeting point, because it is always about the truth of belief they owned, instead of a dialogue about citizenship mediated by independent parties (Fuller, 2011: 8).

The dialogue deadlock about Ahmadiyah religious teaching has taken place since the first of its rejection in 1925. However, although the organization of Islamic scholar rejected Ahmadiyah teachings at that time, there was no violence against them. Ironically, the violence against Ahmadiyah occurred in post-1998, the era of democratic government. The question is why the violence arose after the political reform? It should be underlined that the reform or democratic era did not only signify the transformation of political freedom, but also a period of severe economic crisis due to the global financial crisis since 1997. The economic meltdown contributed to the increasing of the unemployed number. At the same time, there was a growing number of civilian militia groups where most of the partisans are jobless people.

The mushroomed of religious hardliner groups also got influenced by global political constellation. The 9/11 tragedy and the USA invasion of Afghanistan and Iraq, for example, were perceived as a turning point for the Islamic groups to struggle against the Western domination. Therefore, most of the hardliner groups frequently express their resistance toward West policies and actions in Muslim countries. The existence of Ahmadiyah has been frequently linked as the West intervenes to make Indonesia Muslim disunited and always engaged in quarrels. Among the hardliners, the
Ahmadiyah is more than heresy matter, but also represents a symbol of the West wickedness that should be stopped immediately.

The presence of liberalist and pluralist groups who take sides on Ahmadis has amplified allegation about the closeness between Ahmadiyah and the Western counterparts. Ahmadiyah then became an object of a great dispute between conservatives and liberalist groups about how the country should signify democracy. The conservatives, such as FPI, MMI (Indonesia Mujahidin Council), and Laskar Jihad (Jihad Force) regard democracy should not disrupt religious ease and strongly reject pluralism in religious life. They often use mass power and act as a police to crush things they consider as contradict to Islam values (Ali, 2006: 99). The presence of liberalist groups allegedly received funding from the United States and in line with Western imperialism (Husaini \& Hidayat, 2002: 172).

From the otherside, theliberalistandpluralist groups view the democracy should celebrate pluralism, toleration, and be dissociated from religious authority intervention. Corresponding to Ahmadiyah issue, the conservative group considers the presence of Ahmadiyah is part of a liberal agenda that supported by foreigners to destroy the purity of Islam in Indonesia. This view has been established on since the beginning of the Ahmadiyah rejection in Sumatra. Ahmadiyah group was believed to be loyalists of Queen Victoria, which was formed in order to provoke a political clash in Muslim colonial countries (Ropi, 2010: 285). The liberalist and pluralist groups accused the conservative groups obtaining financial support from Saudi Arabia to spread their ideology in Indonesia. They see the violence against Ahmadiyah carried by the conservatives is a proof that the Saudi Arabia values and ideology is unacceptable in Indonesia democratic life. The dimensions of the conflict become complicated because some NU scholars, Musthofa Bisri and Said Agil Siradj tends to support the JIL movement and helped provide discourse against conservative groups. Thus, the conservatives had to face some of NU elites when attacking Ahmadiyah.

Another problem around Ahmadiyah conflict is related to the subjectivity of religious freedom meaning. The pro-Ahmadiyah perceived the banning of Ahmadiyah activities in public 
space was controvert to the national constitution that guarantees the freedom of religion. On the other side, the anti-Ahmadiyah considers the presence of Ahmadiyah has tarnished Islam and created inconvenience for the Muslims. The constitution is also called the state to protect the freedom of all religious adherents who do not want their religion being spoiled by other groups' effort. Thus, it was not easy at all for the government to resolve the conflict with mixture dimension of religious issues and the authority contest between religious leaders and camps that brought their own civilian militia group. Adnan Buyung Nasution said that the decree was actually against Ahmadis discrimination and its purposes to limit the movement of Ahmadiyah in order to avoid a wider conflict (Fuller, 2011: 12).

\section{CONCLUSION}

The conflict of Ahmadiyah was not solely about the heresy issue that charged on the Ahmadis, but involving the calsh of values, ideas, and authorities between the liberalist or pluralist groups and the conservatives who struggle to control democracy. The Ahmadiyah themselves became a commodity issue of the conflicting parties. There was no real action, a dialogue for example, which initiated by the liberalist group or pluralist group with the conservatives and government to seek resolutions at least to put aside the Ahmadis from the violent undertaking. The presence of hostility between liberalist group and pluralist group versus the conservatives has complicated the problem that besets Ahmadiyah.

While most studies explain the central problem of Ahmadiyah case is the strengthening of intolerance and radical groups reconciliation in Indonesia. Without denying that explanation, this study saw the Ahmadiyah decree as a policy that intends to anticipate a wider conflict between the two camps who equally have a large amount of mass that do not hesitate to use violent means. If the policy were not issued, the two major camps would be involved in a severe bloody conflict, which in turn could shatter national stability. Using the perspective of public policy functions to provide social order, the enactment of Ahmadiyah decree was a government effort to protect the existence of
Ahmadiyah by banning their activities in public places due to the potential danger to their safety. The role of public policy on religious conflict should be emphasized on community interest as a collective entity and bring social order on the top list to be accomplished than to meet the demands of each opposing party.

\section{REFERENCE}

Ali, D. J. 2006. Manuver elit, konflik, dan konservatisme politik: opini. Yogyakarta: PT LKiS Pelangi Aksara.

Ali, M. 2007. Confrontation and Reconciliation: Muslim Voices of Maluku Conflict (1999-2002). Journal of Indonesian Islam, 1(2), 379-402.

Antaranews.com. 2008. Warga NU Robohkan Papan FPI Cirebon. from http:// www.antaranews.com/berita/104143/ warga-nu-robohkan-papan-fpi-cirebon (diakses 26 September 2015)

As'ad, M. 2009. Ahmadiyah and the Freedom of Religion in Indonesia. Journal of Indonesian Islam, 3(2), 390-413.

Buehler, M. 2008. The Rise of Shari'a by-laws in Indonesian Districts: an Indication for Changing Patterns of Power Accumulation and Political Corruption. South East Asia Research, 16(2), 255-285.

Burhani, A. N. 2014. Hating the Ahmadiyah: The Place of "Heretics" in Contemporary Indonesia Muslim Society. Contemporary Islam, 8(2), 133-152.

Carrow, M. M. 1998. "A Framework for Democracy, Social Values, and Public Policy." In Democracy, Social Values, and Public Policy, ed M. M. Carrow, R. P. Churcill, \& J. J. Corders. Wesport, Conneticut \& London: Greenwood Publishing Group.

Crouch, M. 2009. Indonesia, Militant Islam and Ahmadiyah: Origins and Implications (No. 4). Melbourne: The University of Melbourne.

Dukes, E. F. 1996. Resolving Public Conflict: Transforming Community and Governance. New York: Manchester University Press. 
Fanani,A. F. 2011. Syari'ah by Laws in Indonesia and Their Implications for Religious Minorities. Journal of Indonesian Islam, 5(1), 17-34.

Fuller, A. 2011. Religious Freedom in Indonesia: Curious Cases of Dialogues, Fatwas, and Laws. Journal of Indonesian Islam, 5(1), 1-16.

Gort, J. D., \& Vroom, H. M. 2002. "Religion, Conflict, and Reconciliation." In Religion, Conflict and Reconciliation: Multifaith Ideals and Realities, ed. J. D. Gort, H. Jansen, \& H. M. Vroom. Rodopi.

Hamidi, S., \& Smith, B. J. 2012. "Sisters, Militias and Islam in Conflict: Questioning "Reconciliation" in Nahdlatul Wathan, Lombok, Indonesia." Contemporary Islam, 6, 29-43. http://doi.org/DOI 10.1007/s11562-011-0168-5

Hicks, J. 2013. Heresy and Authority: Understanding the Turn Against Ahmadiyah in Indonesia. South East Asia Research, 22(3), 1-19.

Husaini,A., \& Hidayat, N. 2002. Islam liberal: sejarah, konsepsi, penyimpangan, dan jawabannya. Jakarta: Gema Insani.

Ingram, H. M., \& Smith, S. R. 2011. Public Policy and Democracy. In H. M. Ingram \& S. R. Smith (Eds.), Public Policy for Democracy. Washington: Brookings Institution Press.

International Crisis Group. 2008. Indonesia: Implications of the Ahmadiyah Decree (No. Asia Briefing No. 78). Jakarta: International Crisis Group.

Kriesberg, L. 1973. The Sociology of Social Conflicts. New Jersey: Prentice-Hall, Inc.

Luton, L. S. 1996. The Politics of Garbage: A Community Perspective on Solid Waste Policy Making. Pittsburgh: University of Pittsburgh Pre.
NU.or.id. 2008. GP Ansor Siap Bubarkan Paksa FPI. http://www.nu.or.id/a,publicm,dinamic-s,detail-ids, 1-id, 12588lang,id-c,warta-t,GP+Ansor+Siap+Bu barkan+Paksa+FPI-.phpx (diakses 26 September 2015)

Peoples, C.D.,\& Gortari, M. 2008. “The Impact of Campaign Contributions on Policymaking in the U.S and Canada: Theoretical and Public Policy Implications." Politics and Public Policy, ed. In H. Prechel. Bingley: Emerald Group Publishing.

Rodgers, J. 2003. Reason, Conflict and Power: Modern Political and Social Thought from 1688 to the Present. USA: University Press of America.

Ropi,I. 2010. Islamism, Government Regulation, and The Ahmadiyah Controversies in Indonesia. Al-Jami'ah, 48(2), 281-320.

Schlee, G. 2010. How Enemies Are Made: Towards a Theory of Ethnic and Religious Conflict. New York: Berghahn Books.

Sewell, J. W. 2005. "The Changing Definition of Development and Development Cooperation." In Comparative Politics: Comparative public policy, ed. H. J. Wiarda. London: Taylor \& Francis.

Svensson, I. 2013. Ending Holy Wars: Religion and Conflict Resolution in Civil Wars. Queensland: Univ. of Queensland Press.

Wilensky, H. L. 2002. Rich Democracies: Political Economy, Public Policy, and Performance. California: University of California Press.

Wilson, C. 2008. Ethno-religious Violence in Indonesia; From Soil to God. London $\&$ New York: Routledge.

Woll, P. 1981. Public Policy. USA: University Press of America. 